\title{
Hygienic behaviors of honey bees in response to brood experimentally pin-killed or infected with Ascosphaera apis*
}

\author{
María Alejandra PALACIO ${ }^{1 *}$, Edgardo RodriguEZ $^{2}$, Lionel GonCALVES $^{3}$, \\ Enrique BEDASCARRASBURE ${ }^{4}$, Marla SPIVAK ${ }^{5}$ \\ ${ }^{1}$ INTA- FCA-UNMdP, CC 276, Balcarce, CP. 7620, Argentina \\ ${ }^{2}$ FCV-UNCPBA, Paraje Arroyo Seco, Tandil CP. 7000, Argentina \\ ${ }^{3}$ FFCLRP-USP, Campus Universitario, Ribeirao Preto, SP, Brazil \\ ${ }^{4}$ INTA Famaillá, Tucumán, Argentina \\ ${ }^{5}$ University of Minnesota, Dept Entomology St Paul, Minnesota, USA
}

Received 29 April 2009 - Revised 28 November 2009 - Accepted 1st December 2009

\begin{abstract}
Hygienic behavior of honeybees involves inspection, uncapping and removal of diseased and dead brood from the colony. The objective of this work was to study the activities involved in hygienic behavior of individually tagged bees from selected hygienic $(\mathrm{H})$ and non-hygienic $(\mathrm{NH})$ colonies in the presence of chalkbrood infected brood (Ascosphaera apis) or pin-killed brood. No significant difference was detected in the age of bees inspecting, uncapping or removing brood in $\mathrm{H}$ and $\mathrm{NH}$ colonies; the median age was 15 days for all activities. The percentage of bees that performed these activities was significantly higher in $\mathrm{H}$ colonies. In $\mathrm{NH}$ colonies the bees that performed this behavior were more persistent but bees in $\mathrm{H}$ colonies were more efficient in the removal of the chalkbrood mummies. $\mathrm{H}$ colonies began uncapping more rapidly in response to the stimulus of dead brood independent of the method used to kill it. $\mathrm{H}$ and $\mathrm{NH}$ bees took the same amount of time to remove the mummies once they initiated the uncapping process but $\mathrm{NH}$ colonies took longer to remove pin-killed brood. These findings confirm previous behavioral studies on the activities of hygienic and non-hygienic bees toward freeze-killed brood, but this is the first time the entire process from inspection to removal was focused on individual cells containing actual diseased brood.
\end{abstract}

Apis mellifera / hygienic behaviour / polyethism / Ascosphaera apis

\section{INTRODUCTION}

Hygienic behavior is an economically important form of social immunity in a honey bee colony (Wilson-Rich et al., 2009). Hygienic behavior is a genetic trait, thought to be controlled by two to seven loci (Rothenbuhler, 1964; Milne, 1985a, b; Moritz, 1988; Kefuss et al., 1996; Thakur et al., 1997; Gramacho, 1999; Lapidge et al., 2002). Individual adult bees that express the hygienic trait uncap and remove diseased brood from combs before the pathogen is transmissible, thus re-

Corresponding author: M.A. Palacio, tiruggi@infovia.com.ar

* Manuscript editor: Stan Schneider ducing the spread of infection in the colony (Rothenbuhler, 1964a, b). At the colony level, hygienic behaviour is a mechanism of resistance to two brood diseases, American foulbrood and chalkbrood (Park et al., 1937; Woodrow and Host, 1942; Rothenbuhler, 1964a, b; Gilliam et al., 1983; Milne, 1983; Taber, 1986; Spivak, 1996; Palacio et al., 2000; Spivak and Reuter, 2001). Hygienic behavior also has been studied as one colony-level mechanism of resistance to the parasitic mite, Varroa destructor, through the bees' removal of infested pupae (Boecking and Drescher, 1992, 1994; Moretto, 1993; Spivak, 1996; Spivak and Reuter, 1998). 
Hygienic bees respond to odour cues that stimulate them to detect, uncap and remove diseased, parasitized and dead brood (Rosenkranz et al., 1993; Palacio et al., 1996; Masterman et al., 1998; Gramacho, 1999). In lab studies, Masterman et al. (2000) demonstrated that bees bred for hygienic behavior were able to discriminate better between odours of healthy and diseased brood compared to bees not bred for hygienic behavior (non-hygienic bees) and concluded that the two lines of bees displayed differential olfactory sensitivity. Gramacho and Spivak (2003) reported that honey bees collected during uncapping had greater olfactory sensitivity than honey bees collected during brood removal, which could explain task partitioning of uncapping and removing brood among bees within a hygienic colony (Arathi and Spivak, 2001). In a recent study, the key compounds associated with Ascosphaera apis-infected larvae were isolated and were found to induce hygienic behavior in field bioasssays (Swanson et al., 2009). However, it is possible that other stimuli also may be involved; Gramacho et al. (1997) suggested that brood temperature could be a physical stimulus for hygienic behaviour.

The important components of hygienic behavior consist of the initial stage of inspection or detection of the diseased brood by an individual bee, and the opening of the wax cap (uncapping) over the diseased pupa and the subsequent removal of the diseased pupa from the comb by many bees. Most studies have studied the hygienic behaviors of bees through periodic scan and focal observations (Spivak and Gilliam, 1993; Palacio et al., 2001); infrared photography (Thakur et al., 1997), and video recording (Arathi et al., 2000). No studies have focused on specific cells containing diseased brood to document the entire process from detection to removal over time.

In most studies of hygienic behavior, the bees were not presented with diseased brood. Instead, hygienic behavior was experimentally elicited either by piercing healthy pupae through the cell capping with a pin to kill it (Cosenza and Silva, 1972; Newton et al., 1975; Gilliam et al., 1978; Message, 1979; Milne, 1982; Taber, 1982; Spivak and Gilliam, 1991) or by freezing a section of wax-capped pupae (Goncalves and Kerr, 1970; Reuter and Spivak, 1998). Rothenbuhler and students (Rothenbuhler and Thompson, 1956; Rohenbuhler, 1964a, b) elicited hygienic behavior by inoculating larvae with Paenibacillus larvae the bacterium that causes American foulbrood, but they did not observe the process of detection and removal by the bees; they only counted the number of larvae that were removed by the bees at the termination of the experiment.

The main objective of this work was to study the behaviors of individually tagged bees from selected hygienic and non-hygienic colonies through the entire process of inspection, uncapping, and removal of specific cells of brood that were experimentally infected with Ascosphaera apis, the pathogen that causes chalkbrood disease. The behaviors of bees toward diseased brood were compared with their behaviors toward pin-killed brood, a common assay used to elicit hygienic behavior. The hypothesis was that bees in hygienic and non-hygienic colonies would differ in the frequency (number of visits per bee) to the diseased or dead brood, and the duration (average and total time) spent inspecting, uncapping and removing the brood. If the stimuli differ between diseased and dead brood, the expression of hygienic behavior could also differ between the lines of bees at the colony-level when they initiate and finish the uncapping and removal processes, and the proportion of diseased and dead brood that are uncapped and removed.

\section{MATERIALS AND METHODS}

Two different experiments were performed in INTA-FCA Balcarce Argentina. The honey bees were obtained from the MeGA Program in Argentina (Palacio et al., 2000). The colonies in this breeding program were selected for hygienic behavior for 10 generations. The pin-killed brood assay was used to select colonies for hygienic behavior (Newton and Ostasiewski, 1986; Palacio et al., 1996).

Hygienic colonies $(\mathrm{H})$ were selected if they removed more than $90 \%$ of pierced brood within 24 hours. Non-Hygienic colonies $(\mathrm{NH})$ removed less than $50 \%$ of pierced brood within 24 hours. All 
queens were allowed to mate naturally with drones from colonies in the selection program.

In both experiments observation hives were used. Each observation hive was comprised by removing a brood comb containing larvae and pupae of different ages from $\mathrm{H}$ and $\mathrm{NH}$ colonies chosen from the breeding program. The comb was introduced in the observation hive and $500 \mathrm{~g}$ of honeybees from the same $\mathrm{H}$ or $\mathrm{NH}$ colony were introduced. After bees uniformly covered the comb a new mated queen from the corresponding $\mathrm{H}$ or $\mathrm{NH}$ line was introduced. The observation hives were fed during all trials with sugar syrup (sugar:water 2:1) using external feeders.

A section of comb was cut out of the middle of the brood comb in each observation hive, leaving a $10 \mathrm{~cm} \times 5 \mathrm{~cm}$ opening. In its place, a section of brood comb of the same dimension was introduced that contained pupae infected with Ascosphaera apis spores. To obtain infected pupae, fifth instar larvae were individually given a dose of $5 \times 10^{5}$ spores in $5 \mu \mathrm{L}$ of food (honey and water solution 1:1) near the mouthparts. Approximately 20 larvae were inoculated in each section of comb. Sections of brood comb with inoculated larvae were chilled $\left(18 \pm 2{ }^{\circ} \mathrm{C}\right)$ for 24 hours to create ideal conditions for fungal development (Puerta et al., 1994); and later were introduced into a field colony to allow the bees to cap over the larvae with wax. After 24 hours, the comb sections containing inoculated larvae were removed from the field colonies and were incubated at $25 \pm 2{ }^{\circ} \mathrm{C}$ (Flores et al., 1996) for seven days until the larvae became mummified from the chalkbrood infection. These brood combs were inspected visually through a light source to record the presence of chalkbrood mummies inside the cells. Cells containing mummies were numbered to identify them individually during filming.

The comb sections containing mummies were introduced into the observation hives in the hole left in the original brood comb. The number of cells with mummies varied from 3 to 7 per comb section because most of the original 20 inoculated larvae were detected and removed from the comb during the 24 hours when they were introduced into the field colonies to be capped with wax. However, sufficient mummies were obtained to provide the first documentation of the entire process of hygienic behavior toward these individual cells containing diseased brood.

In front of one side of each observation hive a video filming camera Panasonic AG-DP200E was installed and connected to a monitor to observe the filming. Anti-reflection glass was used to enhance the filming images. Filming began after introducing the sections of brood comb containing mummies. Filming lasted for 3, 6 or 9 hours (each tape recorded for 3 hours) according to the bees activities on the cells. Images were analyzed using Observer Video-Pro (Noldus $^{\mathrm{R}}$ ).

\section{Experiment 1. Hygienic activities of bees toward diseased brood}

To study the activities performed by honeybees toward cells containing brood infected by $\mathrm{As}$ cosphaera apis in hygienic $(\mathrm{H})$ and non-hygienic $(\mathrm{NH})$ colonies four observation hives were installed, two $\mathrm{H}$ colonies and two $\mathrm{NH}$ colonies.

A brood comb with emerging bees was removed from each of the original $\mathrm{H}$ and $\mathrm{NH}$ colonies. These caged combs were placed in an incubator $\left(36^{\circ} \mathrm{C}\right.$ and $60 \% \mathrm{RH}$ ). Emerging honeybees were individually tagged using Opalithplatchen labels and were introduced in the observation hives. A different colour tag was used each day to record the age of the honey bees. Two hundred bees were labelled each day and a total number of 1200 labelled bees were present in each colony when observations begun. Observations began when the tagged honeybees age varied between 3 and 21 days.

Each time a tagged honey bee performed an activity on the cells containing mummies the following data were recorded: (1) number of bee tag; (2) time the honey bee arrived at the cell; (3) activity performed (inspection, uncapping or removal) (4) time the honey bee left the cell.

The frequency of tagged honeybees performing different activities on cells with mummies was recorded throughout the filming period. The total time and average time invested by a single bee in a specific activity was also recorded, as well as the duration of each visit of a bee performing a specific activity. The age of honey bees performing different activities was also recorded. Finally, the percentage of mummies removed by both groups of bees was calculated.

The percentages of honeybees performing an activity in $\mathrm{H}$ and $\mathrm{NH}$ colonies were compared with Chi-square test. Variables related to time invested in each activity were analyzed with Wilcoxon test. Honey bee age was analyzed with a t-test. Statistical analyses were carried out with FREQ, NPAR1WAY and TTEST procedures of Statistical Analysis Systems, Version 9.1.3 (SAS, Institute Inc., Cary, NC, USA). 


\section{Experiment 2. Comparison of hygienic activities of bees toward diseased brood and pin-killed brood}

For this experiment, sections of sealed brood comb containing chalkbrood mummies (M) were obtained as in Experiment 1. A second piece of comb was obtained from the original colony (either $\mathrm{H}$ or $\mathrm{NH}$ ) and 5-7 cells containing live, healthy pupa were perforated with a pin, (PB), and 5 undisturbed sealed pupae were considered as controls (C). Both comb pieces were introduced into the observation hives before filming began. The images were analyzed using Observer Video-Pro. Each cell containing dead brood (M or PB) was considered as the subject that received the behavior (cell state). It was recorded if the cell was capped or if was being inspected, uncapped, removed, or if no activity was observed

The initial and final time for uncapping and removal of each cell containing a mummy or pinkilled pupa were recorded. When the end of an activity was not observed, it was indicated as being more than $32400 \mathrm{~s}$ (three tapes worth of filming). It was also registered when mummies were removed intact (in one piece).

The variables analyzed were initial and final time of uncapping and removing, frequency and total duration (in seconds) of each group ( $\mathrm{H}$ and $\mathrm{NH})$ and treatments. (M and PB). A Kruskal-Wallis test was used to analyze data related to the time spent in each activity and multiple comparisons were done to detect differences between treatments
(Lee, 1992). Differences were considered significant when $P<0.05$.

Percentages of dead brood that were uncapped and removed after nine hours of filming were calculated and analyzed by Fischer's Exact Test. This test was also used to analyze percentages of brood that were removed intact (the entire pupa removed) or in pieces in different treatments.

Statistical analysis were carried out NPAR1WAY and FREC procedures of, Statistical Analysis Systems, Version 9.1.3 (SAS, Institute Inc., Cary, NC, USA).

\section{RESULTS}

\section{Experiment 1. Hygienic activities of bees toward diseased brood}

Significantly more tagged bees in $\mathrm{H}$ colonies as compared to bees in NH colonies were observed inspecting (Chi-square = 133.17; $P<0.0001$ ), uncapping (Chisquare $=40.824 ; P<0.0001)$ and removing (Chi-square $=17.4599 ; P=0.000029)$ the diseased brood containing chalkbrood mummies from cells (Tab. I, tagged bees).

There was no significant difference between $\mathrm{H}$ and $\mathrm{NH}$ bees in the mean number of visits per bee inspecting a cell containing the chalkbrood mummies (Chi-square = 4.8920; $P=0.17988)$. The few NH bees that were observed made significantly more visits

Table I. Average values for the proportion of tagged bees, visits/bee, visit duration, total time, and average time the bees in the $\mathrm{H}$ and $\mathrm{NH}$ colonies spent inspecting, uncapping and removing the chalkbrood mummies from the cells $(n=2100)$. Proportions followed by different letters show significant differences between the lines of bees for the variable measured.

\begin{tabular}{lccccc}
\hline Activity & $\begin{array}{c}\text { Bee } \\
\text { line }\end{array}$ & $\begin{array}{c}\text { Tagged } \\
(\%)\end{array}$ & $\begin{array}{c}\text { Visits/bee } \\
\text { mean } \\
(\text { min-max })\end{array}$ & $\begin{array}{c}\text { Visit duration } \\
(\text { second }) \\
\text { median }(\mathrm{Q} 1-\mathrm{Q} 3) .\end{array}$ & $\begin{array}{c}\text { Total time } \\
(\text { second }) \\
\text { median }(\mathrm{Q} 1-\mathrm{Q} 3)\end{array}$ \\
\hline INSPECTING & & & & & \\
\hline & $\mathrm{H}$ & $16.57^{\mathrm{a}}$ & $2.85(1-40)^{\mathrm{a}}$ & $11(6-21)^{\mathrm{a}}$ & $16(7-41)^{\mathrm{a}}$ \\
\hline $\mathrm{NH}$ & $5.43^{\mathrm{b}}$ & $3.16(1-41)^{\mathrm{a}}$ & $5.5(14-28)^{\mathrm{a}}$ & $23(7-76)^{\mathrm{a}}$ \\
\hline UNCAPPING & & & & & \\
\hline & $\mathrm{H}$ & $4.29^{\mathrm{a}}$ & $2.48(1-30)^{\mathrm{a}}$ & $37(13.1-77.9)^{\mathrm{a}}$ & $62(21-135)^{\mathrm{a}}$ \\
\hline NH & $1.10^{\mathrm{b}}$ & $6.04(1-22)^{\mathrm{b}}$ & $59(39-104.1)^{\mathrm{b}}$ & $158(41-511)^{\mathrm{b}}$ \\
\hline REMOVING & & & & & \\
\hline & $\mathrm{H}$ & $3.05^{\mathrm{a}}$ & $2.67(1-19)^{\mathrm{a}}$ & $42(12-130.5)^{\mathrm{a}}$ & $68(19-261)^{\mathrm{a}}$ \\
\hline $\mathrm{NH}$ & $1.19^{\mathrm{b}}$ & $3.36(1-13)^{\mathrm{b}}$ & $110(57-196)^{\mathrm{b}}$ & $222(57-448)^{\mathrm{b}}$ \\
\hline
\end{tabular}




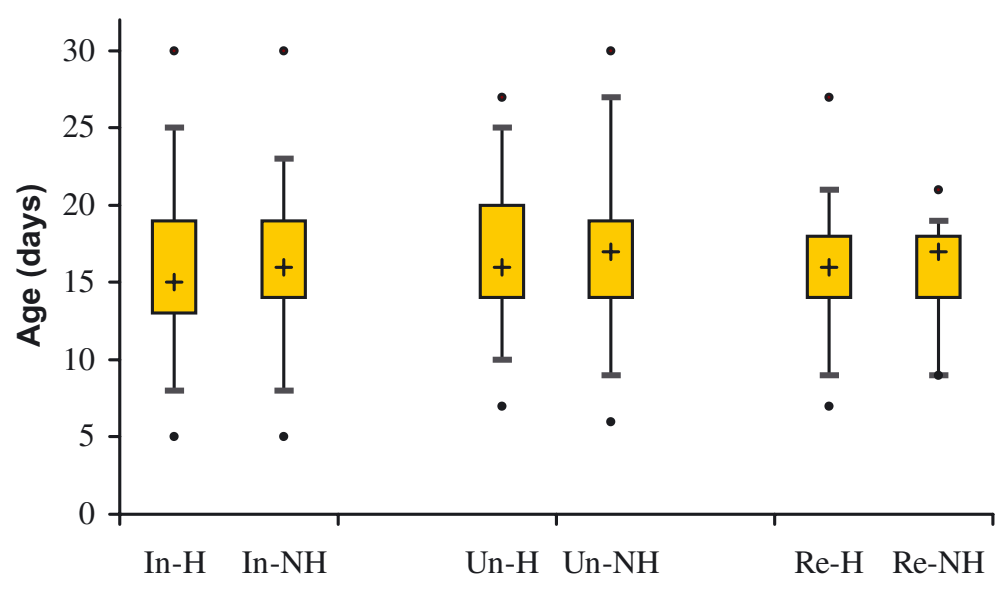

Figure 1. Age of bees (in days) performing activities of inspection, uncapping and removal on cells containing chalkbrood mummies in $\mathrm{H}$ and $\mathrm{NH}$ colonies. In-H: Inspection by Hygienic bees; In-NH: Inspection by Non-Hygienic bees; Un-H: Uncapping by Hygienic bees; Un-NH: Uncapping by Non-Hygienic bees; Re-H: removal by Hygienic bees; Re-NH: Removal by Non-Hygienic bees. The length of the box represents the interquartile range (the distance between the 25 th and the 75 th percentiles). The plus sign inside the box represents the median. The vertical lines issuing from the box represents the 5th and the 95th percentiles. Dots represent the minimum and maximum values.

to uncap $($ Chi-square $=10.3328 ; P=0.016)$ and remove (Chi-square $=5.0746 ; P=0.017$ ) the diseased brood from a cell compared to bees in $\mathrm{H}$ colonies.

The average duration individual bees spent inspecting a cell containing diseased brood did not differ between bees in $\mathrm{H}$ and $\mathrm{NH}$ colonies (Wilcoxon Test $\mathrm{Z}=1.01 ; P=0.3125$ ) But bees in NH colonies spent a significantly longer time uncapping (Wilcoxon Test $\mathrm{Z}=$ 2.4695, $P=0.0135$ ) and removing (Wilcoxon Test $\mathrm{Z}=2.3161, P=0.02060)$ the diseased brood from the cells.

No significant difference was detected in the total time that bees in $\mathrm{H}$ and $\mathrm{NH}$ colonies inspected cells containing chalkbrood mummies (Wilcoxon Test $\mathrm{Z}=1.533, P=0.1253$ ). However tagged bees in NH colonies invested more time in uncapping (Wilcoxon Test $\mathrm{Z}=$ 3.2437, $P=0.0012$ ) and removal (Wilcoxon Test $\mathrm{Z}=2.4900 ; P=0.0128)$ these cells.

The median age of bees performing the three activities in $\mathrm{H}$ and $\mathrm{NH}$ colonies was 15 days $(\min =5 ; \max =30)$, and did not differ significantly among the activities (inspection, $\mathrm{t}=0.76, P=0.4478$; uncapping, $\mathrm{t}=0.43$,
$P=0.6675 ;$ removal, $\mathrm{t}=0.03, P=0.9792)$ (Fig. 1).

Despite the higher number and duration of visits by individual bees from $\mathrm{NH}$ colonies to the diseased brood, bees in $\mathrm{H}$ colonies were more efficient removing the diseased brood from the cells at the colony-level. Over all trials, the $\mathrm{H}$ bees removed $98 \%$ of the chalkbrood mummies introduced in the colonies while the $\mathrm{NH}$ group removed $70 \%$. No re-capping activity was observed on cells where uncapping had begun; once bees had begun uncapping the wax seal over the cell, they finished this task.

\section{Experiment 2. Comparison of hygienic activities of bees toward diseased brood and pin-killed brood}

Bees in $\mathrm{H}$ colonies began uncapping the cells containing either diseased (chalkbrood mummies) or pin-killed brood earlier than bees in NH colonies (Chi-square $=19.77 ; P=$ 0.002) (Fig. 2a). Bees in the NH colonies were more variable in the time to begin uncapping a cell containing pin-killed brood: in one instance, bees did not uncap one cell over the 9 hours (32400 s) of filming. In contrast, the 
(a)

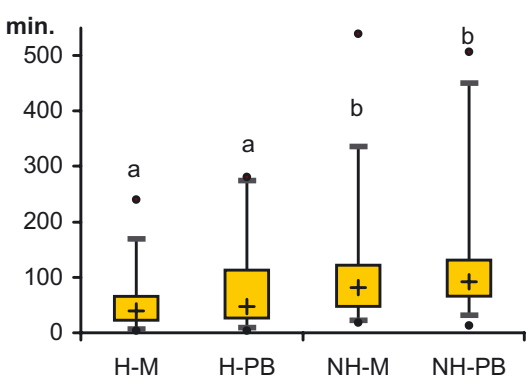

(c)

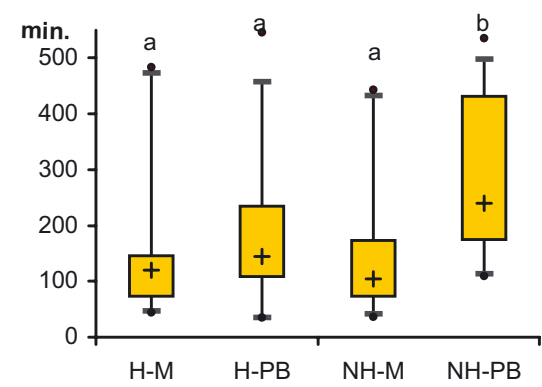

(b)

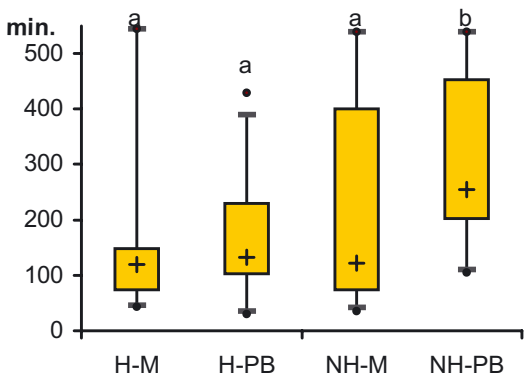

(d)

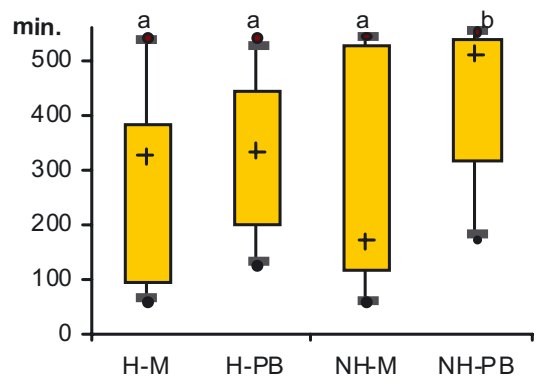

Figure 2. Time distribution in minutes for (a) start of uncapping (Chi-square $=19.77 ; P=0.002$ ), (b) end of uncapping (Chi-square $=9.3244 ; P=0.0002)$, (c) start of removal (Chi-square $=23.2094 ; P<0.0001$ ), (d) end of removal (Chi-square $=16.5490 ; P=0.0009)$ according to group of bees $(\mathrm{H}=$ Hygienic and $\mathrm{NH}=$ Non Hygienic $)$ and treatments $(\mathrm{M}=$ mummies $\mathrm{PB}=$ pierced brood $)$. The length of the box represents the interquartile range (the distance between the 25 th and the 75 th percentiles). The plus sign inside the box represents the median. The vertical lines issuing from the box represents the 5th and the 95th percentiles. Dots represent the minimum and maximum values. Within each graph, different letters above each box designate significant differences among the treatment groups.

maximum value in $\mathrm{H}$ colonies for this variable was 4 hours and 43 min (16980 s).

$\mathrm{NH}$ bees took significantly longer to finish uncapping pin-killed brood and to start and finish removing the pin-killed brood compared to the how long it took them to perform those same activities to cells containing chalkbrood. There were no significant differences among the $\mathrm{H}$ bees in the time to start and finish uncapping and removing cells containing chalkbrood mummies or pin-killed brood (Figs. 2bd).

The efficiency of hygienic behaviour was measured as the proportion of the diseased and pin-killed brood uncapped and removed over the observation period by the $\mathrm{H}$ and $\mathrm{NH}$ bees (Fig. 3). Percentages of uncapped pin- killed and diseased brood were not significantly different within $\mathrm{H}$ colonies and within NH colonies (Fisher's Exact Test $P=0.2578$ ). However, $\mathrm{H}$ colonies uncapped significantly more affected brood overall (both $\mathrm{M}$ and $\mathrm{PB}$ ) compared to NH colonies (Fisher's Exact Test $P=0.0174)$. For removal of the brood, the $\mathrm{H}$ colonies removed significantly more diseased and pin-killed brood compared to the NH colonies (Fisher's Exact Test $P<0.0001$ ) and both $\mathrm{H}$ and $\mathrm{NH}$ removed a greater percentage of diseased brood affected by chalkbrood than pin-killed brood Fisher's Exact Test $P=$ 0.0365 (Fig. 3).

The percentage of brood removed intact did not differ between $\mathrm{H}$ and $\mathrm{NH}$ colonies but mummies were more frequently removed 


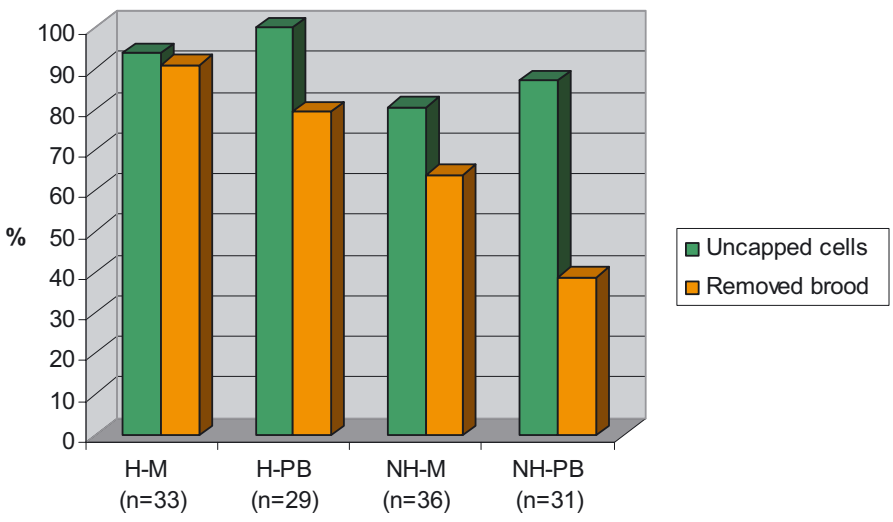

Figure 3. Percentage of cells containing chalkbrood mummies $(\mathrm{M})$ or pin killed brood (PB) that was uncapped or removed after 9 hours filming in hygienic $(\mathrm{H})$ or non-hygienic $(\mathrm{NH})$ colonies. H-M: Hygienic bees activities toward Mummies; H-PB: Hygienic bees toward Pin-killed Brood; NH-M: Non-Hygienic bees toward Mummies; NH-PB: Non-Hygienic bees toward Pin-killed Brood. $\mathrm{n}$ indicates the number of cells.

intact compared to pin-killed brood in both $\mathrm{H}$ $(24.24 \% \mathrm{M}$ vs. $6.89 \% \mathrm{~PB})$ and $\mathrm{NH}(13.89 \%$ $\mathrm{M}$ vs. $3.22 \% \mathrm{~PB}$ ) (Fisher's Exact Test $P=$ 0.0296).

\section{DISCUSSION}

The present work represents the first experimental study on hygienic behavior in which the behavior of individual $\mathrm{H}$ and $\mathrm{NH}$ bees was recorded during the entire process of inspecting, uncapping, and removing brood experimentally infected with the chalkbrood pathogen, Ascosphaera apis. Our results showed that even though only a relatively small percentage of the introduced tagged bees were observed performing these behaviors, significantly more $\mathrm{H}$ bees were observed performing all three behaviors compared to $\mathrm{NH}$ bees. Of the bees that were observed performing hygienic behavior, NH bees spent significantly more time uncapping and removing diseased brood from the cells compared to $\mathrm{H}$ bees. The greater persistence of the bees in $\mathrm{NH}$ colonies did not result in higher overall colony-level efficiency, because $\mathrm{H}$ colonies removed $98 \%$ of diseased brood whereas the $\mathrm{NH}$ colonies removed $70 \%$ within the same time. The age of the tagged bees observed performing hygienic behavior was the same between $\mathrm{H}$ and $\mathrm{NH}$ colonies $($ median $=15 ; 5-30)$.
Bees in $\mathrm{H}$ colonies detected diseased brood (chalkbrood mummies) more rapidly than bees in $\mathrm{NH}$ colonies. But both groups of bees took the same time to remove the chalkbrood mummies. These results indicate that $\mathrm{H}$ bees respond to the initial stimulus of diseased or dead brood more readily by uncapping the brood, but once the cell has been uncapped all bees respond in the same way to removing the chalkbrood infected brood.

Previous research reported that honeybees removed pierced (pin-killed) brood faster than frozen brood (Palacio et al., 1996; Spivak and Downey, 1998). Palacio et al. (1996) suggested that the hole in the wax cap made with the pin could allow the bees to detect the olfactory stimulus easier. Gramacho and Spivak (2003) observed using electroantennogram studies that bees that uncapped pierced brood had less olfactory sensitivity to the odor of chalkbrood mummies (extract of mummies in hexane) compared to bees that uncapped frozen brood. In the present work, bees from $\mathrm{H}$ colonies initiated uncapping of both mummies and pierced brood faster than $\mathrm{NH}$ bees, but within genetic lines there were no differences in how quickly the bees initiated uncapping pierced brood or mummies. Thus, the hole in the wax cap of the pierced brood did not facilitate detection for bees, but the use of fully formed chalkbrood mummies could be 
as strong a stimulus as pierced brood. Even though a fully formed mummy likely presents a strong stimulus, NH colonies in our experiment detected the affected brood later than $\mathrm{H}$ colonies.

Our results confirm those of Arathi et al. (2000) that the proportion of bees performing hygienic activities in an $\mathrm{H}$ colony is relatively low but $\mathrm{H}$ bees are efficient in detecting, uncapping and removing diseased brood. In NH colonies significantly more visits were performed by each individual bee for the three activities considered indicating that the bees in $\mathrm{NH}$ colonies had to work harder to detect, uncap and remove brood affected by Ascosphaera apis from cells.

Masterman et al. (2000) and Gramacho and Spivak (2003) suggested that bees uncapping cells would be the more efficient bees in duties that involve odor discrimination because they identify the odor of abnormal brood. Our results indicate that bees performing inspection likely have higher odor discrimination abilities. In many cases the same bee that performed inspection activities begun to uncap the cell. Robinson and Page (1988) and Frumhoff and Baker (1988) have studied genetic effects on task division in honeybee colonies. Individuals with different genetic backgrounds differ in task performance due to differences in behavioral response threshold for the specific stimulus that elicit a job. Hygienic bees have a lower response threshold to stimulus that elicit hygienic behavior and specifically for uncapping (Masterman et al., 2000; Gramacho and Spivak, 2003). It is possible that the greater percentage of bees in $\mathrm{H}$ group performing inspection activities would be related to them having the lowest threshold for stimulus detection leading to specialization in this job.

In previous studies, bees in $\mathrm{NH}$ colonies have been observed recapping cells that were previously uncapped by other bees (Spivak and Gilliam, 1993; Boecking, 1994, 1999 Thakur et al., 1997; Gramacho, 1999; Arathi and Spivak, 2001; Arathi et al., 2006). No recapping of cells was detected in the present study, but it is possible that the number of cells containing mummies was low enough to allow bees to work frequently on the cells affected.
Most of these authors used freeze-killed or pin-killed brood instead of brood affected by Ascosphaera apis or other brood disease. The most likely explanation for the absence of recapping activities could be the strong odor stimulus of the fully formed chalkbrood mummies, so that even $\mathrm{NH}$ bees were stimulated to continue uncapping and removing the diseased brood.

Hygienic activities are performed by bees aged 15 days old on average. This result agrees with Arathi et al. (2000) but not with Invernizzi and Corbella (1999) that registered 11 day old bees performing hygienic activities. Inspection, uncapping and removal are performed by bees of similar age and no difference was detected between $\mathrm{H}$ and $\mathrm{NH}$ colonies. NH colonies presented a greater dispersion in age of bees $(\mathrm{CV}=30.39 \%)$ performing uncapping than $\mathrm{H}$ colonies $(\mathrm{CV}=$ $20.57 \%$ ). It is possible that the lower proportion of bees performing these activities in NH colonies could be compensated not only by more visits by single bee and more time spent in each visit but also a greater flexibility in age. Arathi and Spivak (2001) suggested that $\mathrm{NH}$ colonies had a reduced behavioral ontogeny rate. However this greater persistence and flexibility in $\mathrm{NH}$ colonies was not enough to remove affected brood as efficiently as $\mathrm{H}$ colonies.

\section{ACKNOWLEDGEMENTS}

We thank Emilio Figini and Analia Martinez for helping with the hygienic bee breeding program. We gratefully acknowledge Cristina Garcia; Guillermo Cuenca Estrada and Jorge Barreto for assistance in bee observation. The National Agency for Promotion Science and Technology (ANPCyT), International Foundation for Science (IFS); National Institute of Agricultural Technology (INTA), Mar del Plata National University (UNMdP) and National University of Centre of Buenos Aires province (UNCPBA) have founded this work.

Comportements hygiéniques des abeilles en réponse à un couvain tué expérimentalement avec une aiguille ou infecté avec Ascosphaera apis.

Apis mellifera / comportement hygiénique / polyéthisme / Ascosphaera / couvain 


\section{Zusammenfassung - Das Hygieneverhalten von Honigbienen gegenüber durch Nadelstich abge- töteter Brut und gegenüber Kalkbrut (Ascos-} phaera apis). Das Hygieneverhalten von Honigbienen beinhaltet die Inspektion und das Entdeckeln von Brutzellen sowie das anschließende Ausräumen kranker Brut. Ziel dieser Untersuchung war es, die Verhaltensreaktionen von Honigbienen unterschiedlichen Alters in hygienischen $(\mathrm{H})$ und nicht hygienischen $(\mathrm{NH})$ Bienenvölkern gegenüber von Kalkbrut (Ascosphaera apis) befallenen Brutzellen zu vergleichen. Weiterhin sollte untersucht werden, ob es Unterschiede in $\mathrm{H}$ und $\mathrm{NH}$ Völkern für dieses Hygieneverhalten gegenüber Brutzellen mit Kalkbrutmumien (M) bzw. mit Nadeln durchstochene Brutzellen (PB) gibt. In zwei Experimenten am INTA-FCA Balcarce, Argentinien, wurden Wabenstücke mit M- bzw. PB-Brutzellen gefilmt. In Experiment 1 wurden schlüpfende Bienen individuell markiert und die Häufigkeit bestimmter Aktivitäten dieser markierten Bienen an M Brutzellen erfasst. In Experiment 2 wurde jede Zelle mit toter Brut (M oder PB) als Subjekt angesehen, an dem ein bestimmtes Verhalten ausgeführt wird. Als Variablen wurden Start- und Endzeit des Entdeckelns und Ausräumens analysiert.

In H-Völkern führten die Bienen signifikant häufiger die entsprechenden Aktivitäten des Hygieneverhaltens aus als in NH-Völkern $(P<0,0001$; Tab. I). Von denjenigen Bienen, die ein Hygieneverhalten ausführten, zeigten die NH-Bienen für alle drei Abschnitte des Hygieneverhaltens signifikant mehr Besuche pro Biene als die H-Bienen. NHVölker brauchten signifikant länger, um Brutzellen mit Mumien zu entdeckeln $(P<0,014)$ bzw. auszuräumen $(P<0,02)$. Von insgesamt 67 Mumien (M) entfernten die H-Völker $89 \%$, die NH-Völker aber nur $70 \%$. Keine Unterschiede zwischen $\mathrm{H}$ und NH-Völkern wurden hingegen beim Alter der Bienen festgestellt, die ein Hygieneverhalten ausführten (Abb. 1).

In Bienenvölkern, die M- und PB-Brut erhielten, begannen die $\mathrm{H}-$ Völker jeweils früher als die $\mathrm{NH}-$ Völker mit dem Entdeckeln der Brutzellen (ChiSquare $=19,77 ; P=0,002 ;$ Abb. 2 ); bei den NH-Völkern war zudem die Varianz bei den MVersuchen deutlich höher. H-Völker räumten signifikant mehr M- und PB-Brutzellen aus als die NHVölker $($ Chi-Square $=15.50 P<0,0001)$ und beide Völkergruppen ( $\mathrm{H}$ und $\mathrm{NH}$ ) räumten mehr M-Brut als PB-Brut aus (Abb. 3).

Bienen in $\mathrm{H}-\mathrm{Völkern}$ waren also effizienter beim Ausräumen von Mumien und vor allem schneller beim Start des Hygieneverhaltens gegenüber toter Brut, unabhängig wodurch diese zuvor abgetötet wurde. Nach Start des Hygieneverhaltens brauchten allerdings $\mathrm{H}$ - und $\mathrm{NH}-$ Bienen genauso lange, um Kalkbrutmumien (M) auszuräumen.

Dies spricht dafür, dass sich H-Bienen vor allem durch eine niedrigere Reizschwelle gegenüber geschädigter Brut auszeichnen. Zudem scheint die
Reaktion gegenüber toter Brut stärker zu sein, wenn diese durch Kalkbrut abgetötet wurde als durch Nadelstich.

\section{Apis mellifera / Hygieneverhalten / Arbeitstei- lung / Ascosphaera apis}

\section{REFERENCES}

Arathi H.S., Spivak M. (2001) Influence of colony genotypic composition on the performance of hygienic behaviour in the honeybee, Apis mellifera L., Anim. Behav. 62, 57-66.

Arathi H.S., Burns I., Spivak M. (2000) Ethology of hygienic behavior in the honeybee Apis mellifera L. (Hymenoptera: Apidae) behavioural repertoire of hygienic bees, Ethology 106, 365-379.

Arathi H.S., Ho G., Spivak M. (2006) Inefficient task partitioning among non-hygienic honeybees, Apis mellifera, and implications for disease transmission, Anim. Behav. 72, 431-438.

Boecking O. (1994) The removal behavior of Apis mellifera L. colonies towards mite-infested brood cells as an defense mechanism against the ectoparasitic mite Varroa jacobsoni Oud., $\mathrm{Ph}$. D. Thesis, Rheinische-Friedrich-WilhelmsUniversitat, Bonn, $127 \mathrm{p}$.

Boecking O. (1999) Sealing up and non-removal of diseased and Varroa jacobsoni infested brood cells in part of the hygienic behavior in Apis cerana, J. Apic. Res. 38, 159-168.

Boecking O., Drescher W. (1992) The removal response of Apis mellifera L colonies to brood in wax and plastic cells after artificial and natural infestation with Varroa jacobsoni Oud. and freezekilled brood, Exp. Appl. Acarol. 16, 321-329.

Boecking O., Drescher W. (1994) Rating of signals which trigger Apis mellifera bees to remove miteinfested brood, Apidologie 25, 459-461.

Cosenza G.W., Silva T. (1972) Comparaçao entre a capacidade de limpeza de favos de abelha africana, da abelha caucasica e de suas hibridas, Ciencia e Cultura 24, 1153-1158.

Flores J.M., Ruiz J.A., Ruz J.M., Puerta F., Bustos M., Padilla F., Campo F. (1996) Effect of temperature and humidity of sealed brood on chalkbrood development under controlled conditions, Apidologie 27, 185-192.

Frumhoff P.C, Baker J. (1988) A genetic component to division of labour within honeybee colonies, Nature 333, 358-361.

Gilliam M., Taber S. III, Richardson G.V. (1983) Hygienic behavior of honeybees en relation to chalkbrood disease, Apidologie 14, 29-39.

Gilliam M., Taber S. III, Rose J.B. (1978) Chalkbrood disease of honey bees Apis mellifera L: a progress report, Apidologie 9, 75-89. 
Goncalves L.S, Kerr W.E. (1970) Genética, Seleçao e melhoramento. 1. Noçoes sobre genética e melhoramento em abelhas, in: Congresso Brasileiro de Apicultura, Florianópolis, pp. 8-36.

Gramacho K. (1999) Fatores q ue interferem no comportamento higienico das abelhas Apis mellifera, Ph.D. thesis, Faculdade de Filosofia, Ciencias e Letras de Ribeirao Preto, Universidade de Sao Paulo, $225 \mathrm{p}$.

Gramacho K, Spivak M. (2003) Differences in olfactory sensitivity and behavioral responses among honey bees bred for hygienic behavior, Behav. Ecol. Sociobiol. 54, 472-479.

Gramacho K., Gonçalves L.S., Rosenkranz P. (1997) Influence of the body fluid of A.m. carnica originated from the brood pin-killed method on the hygienic behavior of worker bees, in: XXXV International Apicultural Congress-Apimondia, Antuerpia-Belgica, Apimondia Publishing House.

Invernizzi C., Corbella E. (1999) Edad de las obreras que realizan comportamiento higiénico y otros comportamientos en las abejas Apis mellifera, Revista de Etología 2, 78-87.

Kefuss J., Taber S. III, Vanpoucke J., Rey F. (1996) A practical method to test for disease resistance in honey bees, Am. Bee J. 136, 31-32.

Lapidge K.L., Oldroyd B.P., Spivak M. (2002) Seven suggestive quantitative loci influence hygienic behavior of honey bees, Naturwissenschaften 89, $565-568$.

Lee E.T. (1992) Statistical method for survival data analysis, John Wiley \& Sons (Ed.), 2nd ed.

Masterman R., Mesce K.A., Smith B.H., Spivak M. (1998) Odor discrimation by hygienic honeybees using proboscis-extension conditioning Apis mellifera, Am. Bee J. 138, 297-298.

Masterman R., Smith B.H., Spivak M. (2000) Brood odor discrimination abilities in hygienic honey bees (Apis mellifera $\mathrm{L}$ ) using proboscis extension reflex conditioning, J. Insect Behav. 13, 87-101.

Message D. (1979) Efeito das condicoes ambientais no comportamento higienico em abelhas africanizadas Apis mellifera L, Ms. Sc. thesis, Faculdade de Medicina de Ribeirao Preto, Universidade de Sao Paulo, $136 \mathrm{p}$.

Milne C.P. Jr. (1982) Laboratory measurement of brood disease resistance. 1. Uncapping and removal of freeze-killed brood by newly emerged workers in laboratory test, J. Apic. Res. 21, 111114.

Milne C.P. Jr. (1983) Honey bee (Hymenoptera: Apidae) hygienic behaviour and resistance to chalkbrood, Ann. Entomol. Soc. Am. 76, 384387.

Milne C.P. (1985a) Laboratory test of honey bee hygienic behavior and resistance to European Foulbrood, Am. Bee J. 125, 578-580.

Milne C.P. (1985b) Estimates of heritabilities and genetic correlation between two components of honey bee (Hymenoptera: Apidae) hygienic be- havior: uncapping and removing, Ann. Entomol. Soc. Am. 78, 841-844.

Moretto G. (1993) Estudo de algumas variaveis relacionadas a um mecanismo de defesa de operarias de Apis mellifera a varroatose e a taxa de reproduçao de ácaro Varroa jacobsoni, Ph.D. Thesis, Faculdade de Medicina de Ribeirão Preto, Universidade de São Paulo, 116 p.

Moritz R.F.A. (1988) A re-evaluation of the two locus model for hygienic behaviour in honeybees (Apis mellifera L.), J. Hered. 79, 257-262.

Newton D.C., Ostasiewski N.J.A. (1986) A simplified bioassay for behavioral resistance to American Foulbrood in honey bees (Apis mellifera L), Am. Bee J. 126, 278-281.

Newton D.C., Cantwell G.C., Bourquin E.P. (1975) Removal of freeze-killed brood as an index of nest cleaning behavior in honey bee colonies (Apis mellifera L), Am. Bee J. 115, 388-406.

Palacio M.A., Figini E., Rodriguez E.M., Rufinengo S., Del Hoyo M.L, Bedascarrasbure, E. (1996) Selección para comportamiento higiénico en una población de Apis mellifera, in: Anales del $\mathrm{V}$ Congreso Iberolatinoamericano de Apicultur, Mercedes, Uruguay, pp. 148-150.

Palacio M.A., Figini E., Rodriguez E.M., Rufinengo S., Bedascarrasbure E., del Hoyo M.L. (2000) Changes in a population of Apis mellifera selected for its hygienic behavior, Apidologie 31, 471-478.

Palacio M.A., Flores J.M., Figini E., Rufinengo S., Escande A., Bedascarrasbure E., Rodriguez E., Gonçalves L. (2001) A Comparative Study of Uncapping and Removing Dead Brood in Hygienic and Non-Hygienic Honeybees, in: XXXVII International Apicultural Congress, Apimondia, Durban, Southafrica.

Park O.W., Pellet F, Paddock F.B. (1937) Disease resistance and American Foulbrood, Am. Bee J. 77, 20-34.

Puerta F., Flores J.M., Bustos M., Padilla F., Campo F. (1994) Chalkbrood development in honeybee brood under controlled conditions, Apidologie 25, 540-546.

Reuter G.S., Spivak M. (1998) A simple assay for honey bee hygienic behavior, Bee Culture 126, 23-25.

Robinson G.E., Page R.E. (1988) Genetic determination of guarding and undertaking in honeybee colonies, Nature 333, 356-358.

Rosenkranz P., Tewarson N., Singh A., Engels W. (1993) Differential hygienic behavior towards Varroa jacobsoni in capped worker brood of Apis cerana depends on alien scent adhering the mites, J. Apic. Res. 32, 89-94.

Rothenbuler W.C. (1964a) Behavior genetics of nest cleaning in honey bees. IV. Responses of F1 and backcross generations to disease-killed brood, Am. Zool. 4, 11-123. 
Rothenbuhler W.C. (1964b) Behavior genetics of nest cleaning in honeybees. I. Responses of four inbred lines to disease killed brood, Anim. Behav. $12,578-583$.

Rothenbuhler W.C., Thompson V.C. (1956) Resistance to American Foulbrood in honey bees. I. Differential survival of larvae of different genetic lines, J. Econ. Entomol. 49, 470-475.

SAS Institute Inc. (1989) SAS/STAT User's Guide, version 6, 4th Edition, V SAS Volume 2, Cary, $\mathrm{NC}, \mathrm{SAS}$ Institute Inc.

Spivak M. (1996) Honeybee hygienic behavior and defense against Varroa jacobsoni, Apidologie 27, 245-260.

Spivak M., Downey D.L. (1998) Field assays for hygienic behavior in disease resistance in honey bees (Apidae: Hymenoptera), J. Econ. Entomol. 91, 64-70.

Spivak M., Gilliam M. (1991) New ideas on the role of hygienic behavior in disease resistant in honeybees, Am. Bee J. 131, 782.

Spivak M., Gilliam M. (1993) Facultative expression of hygienic behaviour of honey bees in relation to disease resistance, J. Apic. Res. 32, 147-157.
Spivak M., Reuter G.S. (1998) Honeybees hygienic behavior, Am. Bee J. 138, 283-286.

Spivak M., Reuter G.S. (2001) Resistance to American foulbrood disease by honey bee colonies Apis mellifera bred for hygienic behavior, Apidologie 32, $555-565$.

Swanson J., Torto B., Kells S., Mesce K., Tumlinson J., Spivak M. (2009) Volatile compounds from chalkbrood Ascosphaera apis infected larvae elict honey bee (Apis mellifera) hygienic behavior, J. Chem. Ecol. 35, 1088-1116.

Taber S. (1982) Bee behavior. Determining resistance to brood diseases, Am. Bee J. 122, 422-423.

Taber S. (1986) Breeding bees resistant to chalkbrood disease, Am. Bee J. 126, 823-825.

Thakur R.K., Bienenfeld K., Keller R. (1997) Varroa defense behaviour in Apis mellifera carnica, Am. Bee J. 137, 143-148.

Wilson-Rich N., Spivak M., Fefferman N.H., Starks P.T. (2009) Genetic, individual, and group facilitation of disease resistance in insect societies, Annu. Rev. Entomol. 54, 405-423.

Woodrow A.W., Host E.C. (1942) The mechanism of colony resistance to American Foulbrood, J. Econ. Entomol. 35, 327-330. 